\title{
Insect Faunal Succession on Buried Piece of Pork in the State of Punjab (India): A Preliminary Study
}

Department of Zoology and Environmental Sciences, Punjabi University, Patiala 147 002, Punjab, India

\begin{abstract}
Forensic entomology is the application and study of insects and other arthropod biology to criminal matters. It involves the interaction of arthropods (mainly insects) with legal activity. Successional studies were carried out on $5 \mathrm{~kg}$ of pork piece used as research model which was clothed with the cotton cloth and buried at a depth of $30 \mathrm{~cm}$ in the forest area of Ghawaddi village of Ludhiana (Punjab) (India). The pork was exhumed two times, in morning and evening. Whole process of decomposition took sixteen days and divided into four decompositional stages- fresh, bloated, active decay and decay stage. Total 10 beetle species belonging to 6 families i.e. Euspilotus assimilis, Saprinus pensylvanicus, Saprinus sp. (Histeridae), Gonocephalum patruele, Typhaea stercorea, Tenebrio molitor (Tenebrionidae), Dermestes maculatus (Dermestidae), Hybosorus sp. (Scarabidae), Pterostichus melanarius (Carabidae) and Necrobia sp. (Cleridae) were observed. From order Hymenoptera 2 species i.e Camponotus compressus and Pheidole indica belonging to family Formicidae were observed during different stages of decomposition.
\end{abstract}

Keywords: Forensic entomology; PMI, Decomposition; Insect succession; Coleoptera; Hymenoptera

\section{Introduction}

Forensic entomology is the study of insects and other arthropods found on a corpse and are used to solve crime especially in medico-legal cases $[1,2]$. Succession is the act of following in order or sequence. The progressive replacement of one dominant insect species or community by another in an ecosystem until a stable climax community is established while Decomposition is a continuous process which is commonly divided into various stages i.e. fresh, bloated, advanced decay and decay stage. Decomposing corpse is an appealing resource to many species of necrophagous, opportunistic and occasional insects $[1,2]$. The identification of insects associated with a corpse and their specific biology in the context of a crime scene can provide useful data for the best estimation of death criteria, i.e. PMI estimation. When studying decomposition from an entomological point of view and for the purpose of applying data to human death investigations, the domestic pig Sus scrofa Linnaeus is considered to be the preferred human analogs [3]. While the pattern of arthropod colonization follows a reasonably predictable sequence, the limits of each stage of decomposition will not necessarily coincide with a major change in the faunal community. Therefore, the stages of decomposition were defined by the observable physical changes to the state of the carcass. A pattern of insect succession results as different carrion insects are attracted to the varying biological, chemical and physical changes a carcass undergoes throughout the process of decay. Main objective of present study was to prepare a database of insects associated with buried corpse, which can have potential importance in estimation of Post Mortem interval in case of buried corpse.

\section{Materials and Methods}

The experiment was conducted in the month of September, 2013, in a village Ghawaddi of District Ludhiana (Punjab), India. Ludhiana district falls in central part of Punjab. The climate of district Ludhiana is hot and semi-arid with mainly dry, hot summer and cold winter except during monsoon season when moist air penetrate into the district. The normal annual rainfall of the district is $680 \mathrm{~mm}$. The soil is sandy loam to clayey with normal reaction ( $\mathrm{pH}$ from 7.8 to 8.5). Long trees of Eucalyptus are main flora. Trunk region of pig (Sus sacrofa) weighing $5 \mathrm{Kg}$, was used as research model to study insect succession pattern in case of buried piece of pork. Piece of pork was clothed with human clothing i.e. some cotton cloth and was buried in the soil. The grave was dug with the help of shovelst and was large enough to accommodate the piece of pork. Depth of the grave was $30 \mathrm{~cm}$. Since this is a common depth for most of homicide cases involving buried bodies so far most homicide victims are not deeply buried. Grave was covered with wire mesh having a layer of local vegetation over it. The pork was exhumed two times a day (morning and evening time) for collection of insects. The entire piece of pork was lifted out and the insects from it were sampled. Insects present on piece of pork were collected with the help of forceps. The tiny insects like ants, collected with the help of fine brush enriched with alcohol. The collected insects were transferred into the vials having $70 \%$ ethanol and were labeled with the date, time, temperature and humidity. All the vials were placed in wooden collection boxes for further identification of insects. The collected insects were identified with the help of Stereozoom (Model No.RI-90-01) microscope and by running the keys based on their morphological characters. The duration of the each decomposition stage varies according to temperature and humidity of area. Ambient air temperature and humidity during the experiment was measured with the help of electronic thermo hygrometer (288-CTH).

*Corresponding author: Madhu Bala, Department of Zoology and Environmental Sciences, Punjabi University, Patiala 147 002, Punjab, India, Tel : +919872129846; E-mail: madhubaladhakane@gmail.com

Received September 08, 2014; Accepted November 07, 2014; Published November 10, 2014

Citation: Bala M, Kaur P (2015) Insect Faunal Succession on Buried Piece of Pork in the State of Punjab (India): A Preliminary Study. J Forensic Res 5: 252 doi:10.4172/2157-7145.1000252

Copyright: (c) 2015 Bala M, et al. This is an open-access article distributed under the terms of the Creative Commons Attribution License, which permits unrestricted use, distribution, and reproduction in any medium, provided the original author and source are credited. 
Citation: Bala M, Kaur P (2014) Insect Faunal Succession on Buried Piece of Pork in the State of Punjab (India): A Preliminary Study. J Forensic Res 5: 252. doi:10.4172/2157-7145.1000252

Page 2 of 4

\section{Results and Discussion}

Understanding the stages of decomposition, the colonization of insects, and factors that may affect decomposition and colonization are key in determining forensically important information about the corpse. Temperature and humidity variation during the experiment was $29 \pm 40^{\circ} \mathrm{C}$ and $67 \pm 4 \%$ (Figures 1 and 2). In entomological studies, stages of decomposition commonly described are: (1) Fresh, (2) Bloat, (3) Active Decay, (4) Post decay (5) Decay stage [4]. During present study four stages of decomposition were observed (Table 1).

\section{Fresh stage}

It begins with the moment of death and continues till the beginning of bloated stage (0-3 $3^{\text {rd }}$ day of experiment). Process of autolysis occurs within the pork that is the breakdown of complex proteins and carbohydrates into simple chemical compounds. No odor is detected during this stage (Figure 3 ).

\section{Bloated stage}

The first sign of this stage is the inflation and swelling and putrefaction of pork. This stage is the beginning of decomposition process. It begins from the $4^{\text {th }}$ day and lasts till $8^{\text {th }}$ day of experiment.

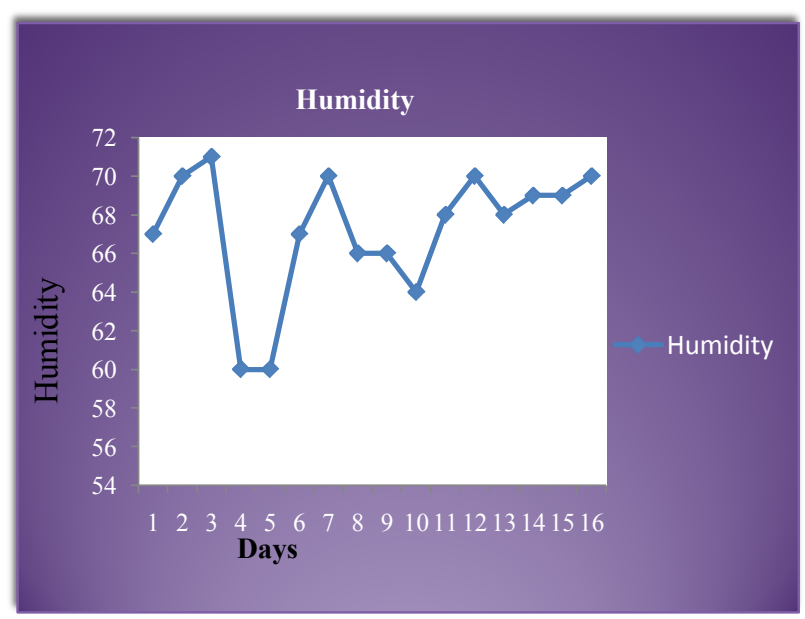

Figure 1: Humidity variation during the experiment.

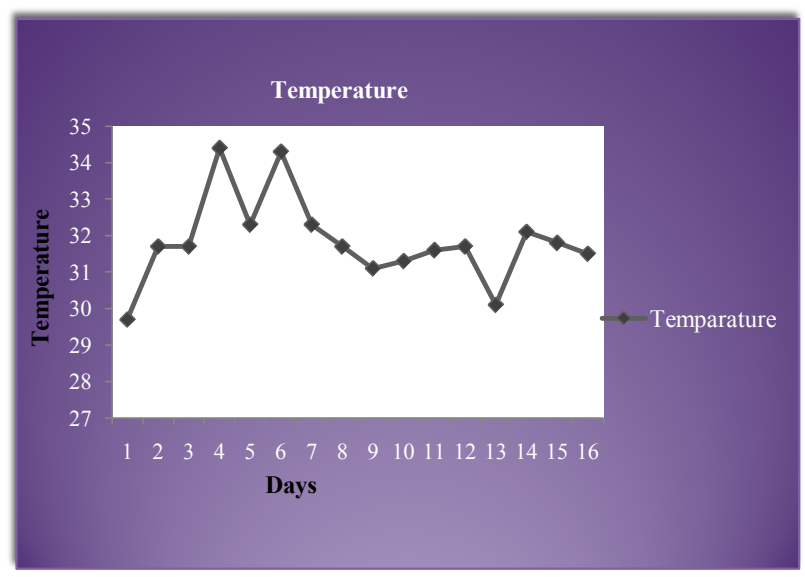

Figure 2: Temperature variations during the experiment.

\begin{tabular}{|c|c|c|c|}
\hline Fresh Stage & Bloated Stage & Advanced Decay Stage & Decay Stage \\
\hline $0-3$ days & $4-8$ days & $9-13$ days & $14-16$ days \\
\hline \multicolumn{2}{|c|}{ Table 1: Duration of Decompositional Stages in Buried Pork. }
\end{tabular}
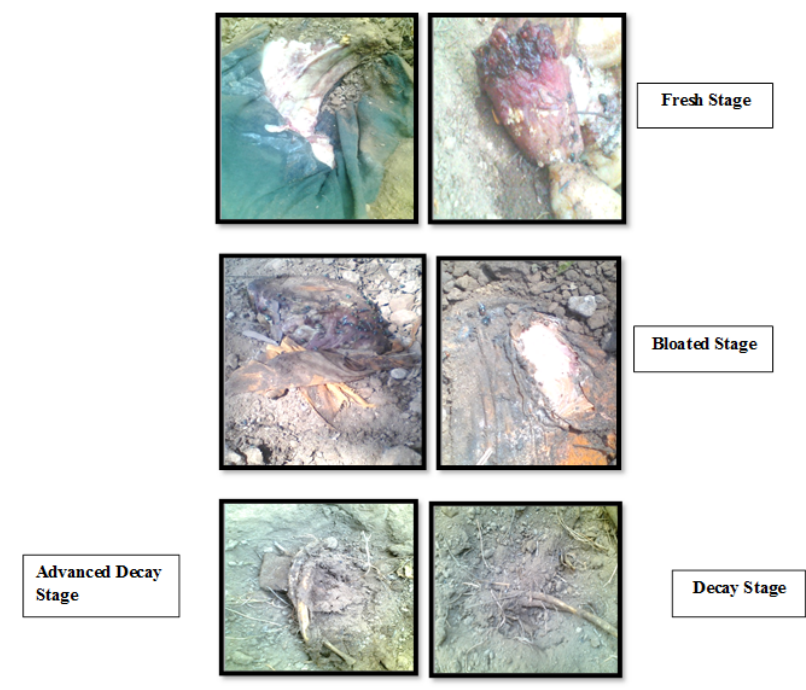

Figure 3: Stages of decomposition in buried pieces of pork.

The inflation caused by gases in the intestine produced due to the action of anaerobic bacteria. Odor of decay is noticed during this stage. Fluid starts seeping from the pork (Figure 3).

\section{Advanced decay stage}

This stage was started on $9^{\text {th }}$ day of experiment and continue upto $13^{\text {th }}$ day. During this stage the pork was deflates and most of the parts were relatively dry (Figure 3 ).

\section{Decay stage}

This stage is the last stage of decomposition, starts on $14^{\text {th }}$ day and continued till $16^{\text {th }}$ day. It contains only the dry skin and bones of pork. The end of this stage is difficult to define due to its long duration (Figure 3).

Reed [5] stated that this stage may last upto a point when no carrion fauna remains. Studies have shown that each stage is characterized by particular insect species, the succession of which is depends on chemical and physical properties of remains, rate of decomposition and environmental factors. Payne [4] described faunal succession patterns on newborn carcasses of the domestic pig, Sus sacrofa Linneaus in a hardwood pine community in South Carolina. Six stages of decomposition were observed on pig carcass.

During present study two insect orders i.e. Coleoptera and Hymenoptera were observed on different decomposition stages. 25 specimens from order Coleoptera belonging to 6 families and 10 species were observed. These are Euspilotus assimilis, Saprinus pensylvanicus, Saprinus sp. belonging to family Histeridae, Gonocephalum patruele, Typhaea stercorea, Tenebrio molitor belonging to family Tenebrionidae, Dermestes maculatus belonging to family Dermestidae, Hybosorus sp. belonging to family Scarabidae, Pterostichus melanarius belonging to family Carabidae and Necrobia sp. belonging to family Cleridae. From order Hymenoptera 13 specimens belonging to 2 species i.e. 
Citation: Bala M, Kaur P (2015) Insect Faunal Succession on Buried Piece of Pork in the State of Punjab (India): A Preliminary Study. J Forensic Res 5: 252. doi:10.4172/2157-7145.1000252

Page 3 of 4

\begin{tabular}{|c|c|c|c|c|c|}
\hline \multicolumn{2}{|c|}{ Insect fauna } & Fresh Stage & Bloated Stage & Advanced Decay Stage & Decay Stage \\
\hline Order & Family & (Species) & (Species) & (Species) & (Species) \\
\hline \multirow{10}{*}{ Coleoptera } & \multirow{3}{*}{ Histeridae } & Saprinus pensylvanicus & Saprinus pensylvanicus & - & - \\
\hline & & Saprinus sp. & _. & - & Saprinus sp. \\
\hline & & Euspilotus assimilis & Euspilotus assimilis & Euspilotus assimilis & - \\
\hline & Dermestidae & - & - & - & Dermestes maculatus \\
\hline & Carabidae & Hybosorus sp. & - & - & - \\
\hline & Scarabidae & - & Pterostichus melanarius & - & - \\
\hline & \multirow{3}{*}{ Tenebrionidae } & - & Gonocephalum patruele & Gonocephalum patruele & Gonocephalum patruele \\
\hline & & - & Tenebrio molitor & - & Tenebrio molitor \\
\hline & & - & - & - & Blapstinus sp. \\
\hline & Cleridae & - & - & Necrobia sp. & - \\
\hline \multirow[t]{2}{*}{ Hymenoptera } & \multirow[t]{2}{*}{ Formicidae } & Pheidole indica & Pheidole indica & Pheidole indica & - \\
\hline & & - & Camponotus compressus & - & - \\
\hline
\end{tabular}

Table 2: Insect fauna associated with Buried piece of pork.

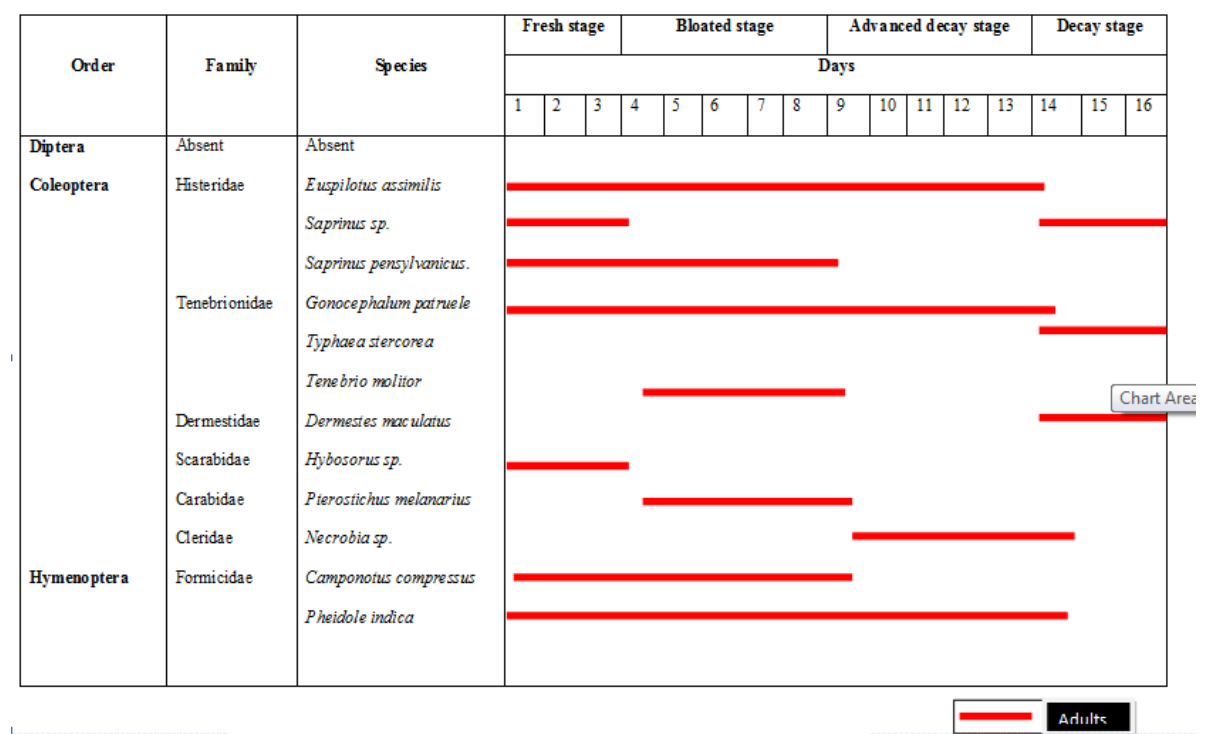

Figure 4: Insect fauna associated on buried piece of pork according to days.

Camponotus compressus and Pheidole indica from family Formicidae were observed during different stages of decomposition. Description on succession pattern of insect order observed on pork piece is given below:

\section{Diptera}

Dipteral flies as well as their immature stages were not observed during any stage of decomposition because the pork was buried at the depth of $30 \mathrm{~cm}$ and flies were not able to reach at such depth since grave was tightly covered with the soil and wire mesh. But Pastula and Merritt [6] observed two fly species on buried pork i.e Sarcophaga bullata (Parker) (Diptera: Sarcophagidae) and Hydrotaea sp. (Diptera: Muscidae) which were found colonizing buried carrion after 5 days of burial at depth $30 \mathrm{~cm}$.

\section{Coleoptera}

25 specimens belonging to 6 families and 10 species were observed during different stages of decomposition. During fresh stage 3 species of beetles belonging to family Histeridae were observed i.e. Saprinus pensylvanicus, Euspilotus assimilis and Saprinus sp. and these were dominating throughout the experiment. Hybosorus sp. belonging to family Scarabidae was also observed during fresh stage. In bloated stage Saprinus pensylvanicus, Euspilotus assimilis: Histeridae, Pterostichus melanarius: Carabidae and Gonocephalum patruele, Tenebrio molitor belonging to family Tenebrionidae were observed. In Active decay stage Euspilotus assimilis belonging to family Histeridae, Gonocephalum patruele belonging to family Tenebrionidae and Necrobia sp. belonging to family Cleridae were observed. In decay stage family Tenebrionidae was dominating, 3 species Gonocephalum patruele, Tenebrio molitor and Blapstinus sp. was found in abundance on the pork piece during the last stage of decomposition. Dermestes maculatus belonging to family Dermestidae was also observed in decay stage (Table 2 and Figure 4). Percentage composition of fauna of order Coleoptera collected from pork is $26 \%$ Histeridae, 26\% Tenebrionidae, 5\% Carabidae, 5\% Dermestidae, 5\% Scarabidae and 2\% Cleridae (Figure 5). Bharti and Singh [7] reported six Coleopteran families i.e. Staphylinidae, Histeridae, Cleridae, Dermestidae, Tenebrionidae and Silphidae on rabbit carrion. Reed [5] reported three beetle families (Scarabidae, Histeridae and Staphylinidae) on pig carcass. Deikeirsschieter et al. [8] studied the succession in Europe on pig carcasses. The work reported here mentioned the presence of carrion beetles (Coleoptera: Silphidae) on decaying pig carcasses in four selected biotopes (forest, crop, field and urban site) at the beginning of spring. Daria et al. [9] studied 


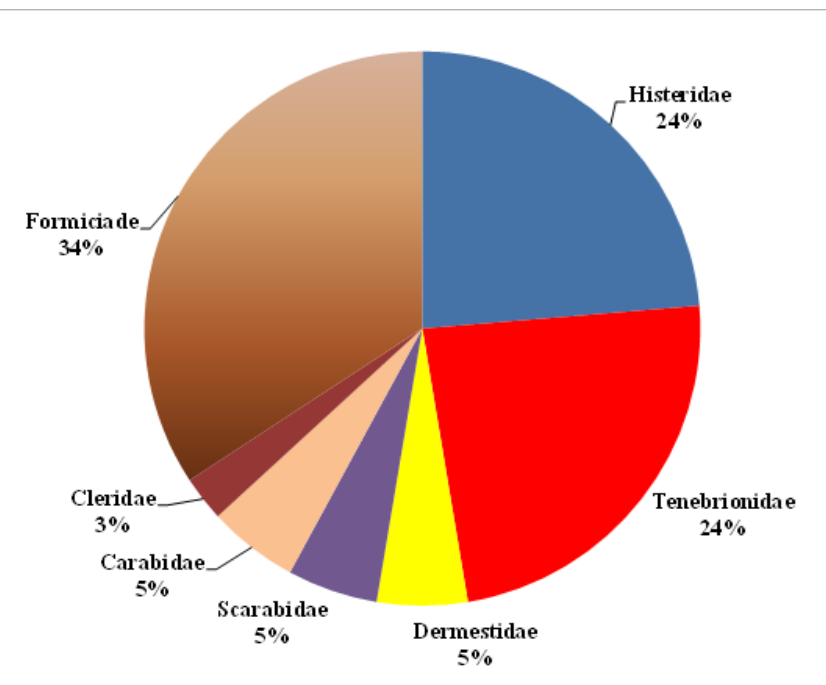

Figure 5: Percentage of insect fauna associated on buried piece of pork.

seasonality, habitat preference and residency on carrion of histerid beetles while studying succession of insects on 36 pig carcasses (mean weight $=25.8 \mathrm{~kg}$ ) in spring, summer and autumn, in pine-oak forest, hornbeam-oak forest, and alder forest (2 carcasses/forest/ type/season/ year). Anton et al. [10] studied the forensic implication of beetles and flies collected on pig carrion in an experimental setting in Thuringia.

\section{Hymenoptera}

Ants were found in abundance on the pork piece. $34 \%$ of insect fauna associated with pork decomposition belongs to family Formicidae of order Hymenoptera (Figure 5). Total 13 specimens belonging to 2 species i.e. Camponotus compressus observed during bloated stage and Pheidole indica observed during fresh, bloated and active decay stage of decomposition (Table 2 and Figure 4). Singh and Bharti [11] observed eight species of family Formicidae (Hymenoptera) on rabbit carrion. Payne and Mason [12] reported 82 species of Hymenoptera on pig carrion.

\section{Conclusions}

The pork was completely decomposed within sixteen days, and four decomposition stages were observed i.e. fresh, bloated, active decay and decay stage. The decomposition was occur mainly due to bacterial activity and as well as by the activity of two insect orders i.e. Coleoptera and Hymenoptera. Total 25 specimens belonging to 6 families and 10 species of beetles i.e. Euspilotus assimilis, Saprinus pensylvanicus, Saprinus sp. (Histeridae), Gonocephalum patruele, Typhaea stercorea, Tenebrio molitor (Tenebrionidae), Dermestes maculatus (Dermestidae), Hybosorus sp. (Scarabidae), Pterostichus melanarius (Carabidae) and Necrobia sp. (Cleridae) were observed. From order Hymenoptera 13 specimens belonging to 2 species i.e Camponotus compressus and Pheidole indica of family Formicidae were observed during different stages of decomposition. Studies on insect faunal succession pattern in case of buried pork have important implication in medico legal investigations. Insect succession on carrion can provide useful information to determine PMI, days of burial etc. If a body is found buried in soil, the entomological data can be helpful in determining the period intervening death and burial.

\section{References}

1. Haskell NH, Williams RE (2009) Entomology \& Death: A Procedural Guide, 2nd ed., Forensic Entomology Partners, Clemenson, S. C., USA

2. Byrd JH, Castner JL (2010) Forensic Entomology - The Utility of Arthropods in Legal Investigation, CRC Press, Boca Raton, Fla., 15.

3. Catts EP, Goff ML (1972) Forensic Entomology in criminal investigations. Ann. Rev. Entomol 9: 245-255.

4. Payne JA (1965) A summer carrion study of baby pig Sus sacrofa Linnaeus. Ecol., $46: 590-602$.

5. Reed HB (1958) A study of dog carcass communities in Tennessee, with specia references to the insects. Am. Midl. Nat 59: 213-245

6. Pastula EC, Merritt RW (2013) Insect arrival pattern and succession on buried carrion in Michigan. J Med Entomol 50: 432-439.

7. Bharti M, Singh $D(2003)$ Insect faunal succession on decaying rabbit carcasses in Punjab, India. J Forensic Sci 48: 1133-1143.

8. Dekeirsschieter J, Verheggen FJ, Haubruge E, Brostaux Y (2011) Carrion beetles visiting pig carcasses during early spring in urban, forest and agricultura biotopes of Western Europe. J Insect Sci 11: 73.

9. Daria B, Matuszewski S and Konwerski S (2011) Insect succession on carrion: seasonality, habitat preference and residency of histerid beetles (Coleoptera: histeridae) visiting pig carrion exposed in various forests (Western Poland). Pol. J. Ecol., 59: 787-797.

10. Anton E, Niederegger S, Beutel RG (2011) Beetles and flies collected on pig carrion in an experimental setting in Thuringia and their forensic implications. Med Vet Entomol 25: 353-364.

11. Singh D, Bharti M (2001) Ants (Hymenoptera: Formicidae) associated with decaying rabbit carcasses. U. P. J. Zool 21: 93-94.

12. Payne JA, Mason WRM (1971) Hymenoptera associated with pig carrion. Proceedings of Entomological Society of Washington 73: 132-141. 